\title{
Reviews
}

\section{Kelly Erby}

\section{Go West, Oxen, Horses, and Mules}

Diana L. Ahmad. Success Depends on the Animals: Emigrants, Livestock, and Wild Animals on the Overland Trails, 1840-1869. $x+132$ pages, notes, bibliography, index. Las Vegas: University of Nevada Press, 2016. \$31.95 (hb).

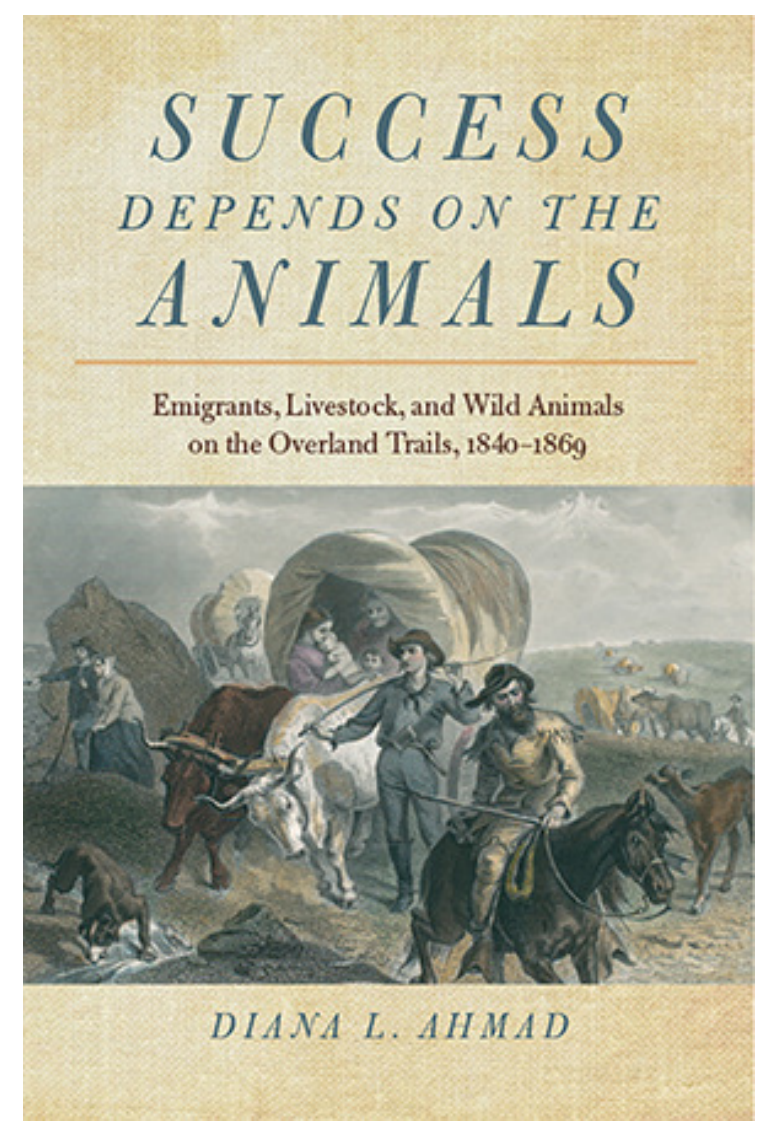

The nearly three hundred thousand men, women, and children who trekked across the North American continent in the mid-nineteenth century looking for a better life in the American West depended on animals to successfully make the journey. As Diana Ahmad demonstrates in Success Depends on the Animals, when these Americans hitched wagons heavy with supplies and belongings to teams of oxen, horses, or mules, they also took with them certain cultural values and preconceptions about the animals on 
which they relied and their relationships with them. The miles they traveled with these animals, however, Ahmad argues, led many emigrants to alter their ideas about their livestock, as well as the wild beasts and pests they encountered along the trail.

In seven brief chapters, Ahmad examines nineteenth-century Americans' concepts about animals, the role that animals played on the overland trails, and the impact of westward migration on the relationships between emigrants and animals. This study fills a significant gap in our historical knowledge of westward migration, for, as Ahmad points out, "hundreds of books have been written about the human experiences on the overland trails, while none have been written about the animals that accompanied the emigrants" (ix). But Ahmad's motivation for writing extends well beyond merely filling a gap; she wants her readers to understand that meaningfully incorporating animals into the history of the overland trails "broadens the historical experience of humans and animals alike" (x). She turns to overlanders' personal diary accounts and letters home for evidence to support this claim.

After a quick overview of the factors driving westward migration between the 1840s-1860s - including the gold rush in California, the opening of new western territories, and ideas about America's manifest destiny to spread democratic and Christian principles across the continent - Ahmad traces the influences that shaped nineteenth-century Americans' mindsets about animals and their relationships with humans. She finds these influences included religious and philosophical teachings, laws, and, even, artwork. Western religions taught that animals lacked souls and that God had created animals to be subservient to men. At the same time, Americans read the Bible to say that humans had a religious responsibility to care for animals. Children learned that abuse of animals insulted God. The law also provided legal protection for animals and guarded against cruelty. Meanwhile, in the landscape paintings that were popular in the early 1800s, including those by Hudson River School artists such as Thomas Cole and George Catlin, animals were used to evoke tranquility, solitude, power, and majesty. These artists employed animals to suggest that nature, in its untouched innocence, should take precedence in the new American Republic over potentially corrupting human civilization and empire. The pervasive nineteenthcentury ideologies of gentility and the cult of domesticity, Ahmad finds, reinforced many of these concepts. "Kindness to animals," Ahmad observes, "became a mark of class identity, while cruelty to animals ... served as a predictor of antisocial behavior in adults" (10). These years thus saw a growth in the keeping of pets, which the wave of advice manuals in this period suggested would help inculcate morality in children. 
With a baseline for nineteenth-century Americans' attitudes toward animals thus established, Ahmad turns in her third chapter to the preparations emigrants made for their westward journeys, focusing on their extensive planning involving animals. She writes: "preparations for the journey west required as much attention to the needs of the oxen, horses, and mules as to the needs of the human travelers" (17). Businesses in the major jumping-off towns for trails bound for Oregon and California, such as Independence, St. Joseph, and St. Louis, Missouri, as well as Kanesville (later renamed Council Bluffs), Iowa, advertised their ability to provide anything emigrants required for the long expedition ahead, including draft animals. As one overlander stated in 1852, "good horses, good mules and good oxen are everything on a journey like this" (21). Ahmad uncovers the factors that influenced emigrants' decisions about what kind and how many animals to purchase to pull their wagons. She explains that oxen, despite the fact that they traveled at one-third to one-half the speed of horses, were the preferred mode of transportation on the trails because they were considered "the safest animals that can be employed upon the road," as well as easier to drive and less likely to be stolen by Native Americans (21). But unlike oxen or mules, horses "had a reputation for being a pleasant team if chosen carefully"; in the absence of such care, however, horses were considered finicky and unlikely to complete the trip successfully (23).

Ahmad also explains the forethought that went into purchasing supplies for draft animals. She recounts, for example, the decision of Finley McDiarmid from Wisconsin who, in May 1856, purchased an extra wagon in which he intended to haul grain for his animals. After the animals had consumed these provisions, McDiarmid abandoned the extra wagon, which freed up the animals that had pulled it and gave him extra teams in case they were needed. By this time, the grasses along the trail had grown sufficiently long in the sun of late spring and early summer to sustain his animals until they carried him to his destination point (23). As the years went on, however, and more and more humans, wagons, and animals traveled the trails, "the opportunities for locating good grass and water for the livestock near the trails declined" (31). Overlanders were forced to carry more supplies to nourish their animals or to venture farther from the trail to find feeding and resting spots for their animals, which added significant time to their crossings.

Ahmad also explains the training that emigrants put into their animals before embarking west. She writes: "most of the emigrants quickly learned that spending time with the animals proved advantageous. The majority of the animals had never been broken, and they needed to become accustomed to human touch and to spoken

Humanimalia: a journal of human/animal interface studies

Volume 10, Number 2 (Spring 2019) 
commands" (24). Ahmad finds that guidebooks and letters from friends who had successfully completed the journey advised overlanders to continue to be thoughtful toward their animals once on the trails. She explains that some authors recommended that "the greatest attention should be paid to all animals that are taken on this journey" and that "the success of the journey 'depends entirely' on the condition of the teams" (25). For example, emigrants were told to drive their animals slowly and not overburden their teams with too much "trumpery" (25).

On the trails, overlanders constantly considered the beasts of burden that pulled their wagons, hauled their supplies, and carried their loved ones. How much farther could they travel before the animals needed to rest? Where could they stop where good water and abundant grass would be available to rejuvenate their animals? How could they prevent a stampede, or the theft of their animals by Native Americans? Did they need to shoe their animals' feet? Should they purchase fresh animals in order to complete their trek? In the terrible event that one of their animals became exhausted or hurt, unable to go on, should they put the animal down to end its suffering, or simply abandon it in the western wilderness? Ahmad argues that from such constant consideration and mutual dependency, deep emotional bonds between human and animal were often forged. She writes: "On the journey from the Missouri River to the Pacific Coast, the overlanders developed a relationship with their four-footed companions that exceeded anything they anticipated and that surpassed their needs of using the animals to simply propel them westward" (51). Ahmad even uses the term "friendship" to describe the special connection between humans and animals on the trails.

But though humans and animals may have been friends, bonded together through hardship and suffering, emigrants nevertheless never forgot these animals also "provided transportation, labor, and revenue" (1). In other words, theirs was first and foremost a working relationship. Accordingly, emigrants sold their animals to the highest bidder or abandoned them to the wilderness (and the wolves) when it benefitted them to do so, or welcomed the addition of fresh meat to their diets their animals may have provided.

Ahmad also describes the contributions of dogs along the trails. She finds that dogs provided companionship as well as helping to herd the teams, locating lost livestock, and guarding camps and other animals throughout the night. The many and various wild animals encountered during the three-to-four-month journey became another part of emigrants' daily routines. According to Ahmad: "The wild animals they encountered ranged from the smallest insects to the largest carnivores. Considering buffalo and antelope savory, wolves and mosquitoes scary, and prairie dogs saucy, most emigrants 
manifested a keen awareness and appreciation for the animal life that surrounded them on the Great Plains, through the deserts, and over the mountains" (67). Ahmad acknowledges that many of these wild animals became sources of food and leather, while others, like prairie dogs, were driven out by settlers carving out new homes. But she also argues they proved endlessly fascinating to emigrants and "symbolized their desires for new homes in the West" because of their abundance (67).

In telling the story of westward migration from the perspective of animals, Ahmad's research contributes to a growing body of scholarship that explores the diversity of the American West and the significance of nonwhite, non-male peoples - or, in this case, animals - to it.

By the time they reached their final destinations, Ahmad writes, "the overlanders came to a new understanding and appreciation of the domestic and wild animals they worked with and encountered" (85). It is not, however, clear what, if any, significance this new understanding may have had in shaping the future way settlers lived, worked, or farmed. Moreover, if, as some scholars have theorized, human dominance over animals provides a foundation for naturalizing power imbalances between peoples including race and gender hierarchies - the newfound "friendships" between humans and animals forged on the overland trails do not seem to have had much of an effect on power dynamics more generally, given the often violent and imperialist history of the American West.

Still, Success Depends on the Animals enriches the history of westward migration and settlement by meaningfully incorporating animals and their contributions into the story. The account is accessible and lively and will appeal to academic and popular audiences alike. Ultimately, it is a tale of compassion and empathy in the face of tremendous obstacles and hardship, as humans and animals alike became "overlanders," reshaping the American frontier.

Humanimalia: a journal of human/animal interface studies

Volume 10, Number 2 (Spring 2019) 